\title{
ANALISIS KEUNGGULAN KOMPARATIF DAN KOMPETITIF SERTA IMPLIKASI KEBIJAKAN PEMERINTAH PADA KOMODITAS JAGUNG DI KABUPATEN BENGKAYANG
}

\author{
DODY RADIANSAH ${ }^{1)}$, RADIAN $^{2)}$, NURLIZA $^{3)}$ \\ 1) Alumni Magister Manajemen Agribisnis Fakultas Pertanian \\ Universitas Tanjungpura Pontianak \\ 2) Staf Pengajar Fakultas Pertanian Universitas Tanjungpura Pontianak
}

\begin{abstract}
The aims of this research are (1) To Analyze the comparative and the competitive advantages of maize in Kabupaten Bengkayang (2) To analyze the impact of the government policy of maize in Kabupaten Bengkayang. The Analyze method use a Policy Analisys Matrix (PAM). The analisys showed that Domestic Resource of Ratio were 0,59 and Private Cost Ratio were 0,81. Both of them are less than one that's mean the maize had the comparative and competitive advantages. To see the government policy of input can be shown from the Nominal Protection Coefficient on Output (NPCO). To see the government policy of input can been shown from the Nominal Coefficient on Input (NPCI) and factor Transfer. Simultanly the government policy if input and output can be shown from the Effective Protection Coefficient Value (EPC), Profitability Coefficient (PC) and Surplus Ratio to Producer (SRP). The analisys result shown that there is no government policy that have been made to the maize output in Kabupaten Bengkayang, right in buying price subsidiary or protection of actual buying price. The government policy to maize input has been shown to the farmer side, but the subsidiary input price not profitable enough to increasment and development of maize product in Kabupaten Bengkayang if not followed by output price policy.

Keyword : Comparative and Competitive Advantages, Policy Analisys Matrix, Maize
\end{abstract}

\section{PENDAHULUAN}

Tanaman pangan utama yang merupakan sumber karbohidrat selain padi adalah tanaman jagung. Tanaman jagung memiliki peluang yang menarik untuk diusahakan karena jagung mempunyai fungsi multiguna, baik untuk pangan maupun pakan. Jagung dapat digunakan sebagai makanan hewan ternak dan juga digiling menjadi tepung jagung (comstarch) untuk produk-produk makanan, minuman, pelapis kertas dan farmasi, sehingga komoditas ini mempunyai prospek pemasaran yang lebih baik dan termasuk komoditas strategis dalam pembangunan pertanian dan perekonomian Indonesia.

Sejalan dengan mudahnya akses informasi dan tingkat pengetahuan masyarakat, kecenderungan untuk mengkonsumsi protein hewani khususnya daging ayam dan telur juga semakin meningkat. Hal ini akan mendorong pengusaha peternak ayam untuk menigkatkan produksinya yang juga akan berdampak kepada meningkatnya kebutuhan jagung untuk pakan ternak. Kondisi ini mengindikasikan besarnya peranan jagung dalam memacu pertumbuhan subsektor tanaman pangan dan perekonomian nasional pada umumnya. Khusus di propinsi Kalimantan Barat, pada tahun 2012 produksi jagung baru mencapai 
170.124 ton sedangkan kebutuhan jagung pada tahun tersebut sebesar 249.998 ton. Sebagian besar jagung tersebut digunakan untuk bahan baku pakan ternak yaitu sebanyak 249.150 ton $(99,66 \%)$, dan sisanya sebanyak 848 ton $(0,34 \%)$ untuk konsumsi atau bahan pangan. Mengingat kebutuhan akan jagung yang semakin meningkat, pemerintah daerah Kalimantan Barat membuat programprogram yang ditujukan kepada kawasan penghasil jagung dengan tujuan untuk memotivasi petani dalam meningkatkan produksi jagung mereka. Salah satu kawasan penghasil jagung terbesar yang ada di Kalimantan Barat adalah Kabupaten Bengkayang. Sebesar $66 \%$ luas panen dan $73 \%$ produksi tanaman jagung yang ada di Kalimantan Barat berasal dari Kabupaten ini, sedangkan sisanya yaitu $44 \%$ luas panen dan $27 \%$ produksi berasal dari 13 kabupaten lainnya. Banyaknya program pemerintah yang mendukung proses produksi usahatani jagung Kab. Bengkayang untuk menjadi sentra jagung seharusnya sejalan dengan pertumbuhan luas panen jagung. Namun sampai saat ini lahan tanaman jagung yang ada di kabupaten ini semakin berkurang. Kondisi usahatani jagung yang terjadi di Kabupaten Bengkayang sebagai sentra terbesar di Kalimantan Barat dalam mengusahakan komoditas jagung juga mengalami penurunan pada jumlah produksi yang dihasilkan.

Pengusahaan jagung tidak terlepas dari adanya campur tangan pemerintah yang berupa kebijakan-kebijakan, seperti kebijakan subsidi, pajak dan perubahan nilai tukar rupiah. Dampak adanya kebijakan pemerintah tersebut seringkali menyebabkan terjadinya perbedaan harga input maupun output dari usahatani jagung sehingga akan berpengaruh terhadap perhitungan finansial maupun ekonomi yang dikeluarkan oleh petani. Sehingga kondisi ini mengisaratkan perlunya dilakukan penelitian dan kajian yang mendalam tentang usahatani dan kebijakan pemerintah terhadap komoditas jagung yang ada di kabupaten tersebut. Usahatani jagung ini diharapkan dapat berperan dalam pemerataan pembangunan melalui perannya dalam meningkatkan pendapatan masyarakat. Tujuan dari penelitian ini adalah menganalisis keunggulan komparatif dan keunggulan kompetitif serta dampak kebijakan pemerintah terhadap usahatani jagung di Kabupaten Bengkayang.

\section{METODE PENELITIAN}

Menggunakan metode survei di sentra jagung Kalimantan Barat yaitu Kabupaten Bengkayang tepatnya di Kecamatan Tujuh Belas, karena sebesar 70\% jagung Kalimantan Barat dihasilkan dari Kabupaten Bengkayang. Data yang digunakan adalah data primer dan data sekunder. Pengambilan sampel digunakan dengan cara sampling acak (random sampling) pada petani jagung di 4 Desa pada kecamatan Tujuh Belas yaitu Desa Bengkilu, Desa Kamuh, Desa Pisak dan Desa Sinar Tebudak. Setiap desa diambil 10 responden, sehingga jumlah seluruh responden 40 orang. Penelitian ini menggunakan Policy Analysis Matrix. 
Tabel 1. Policy Analysis Matrix

\begin{tabular}{|c|c|c|c|c|}
\hline \multirow[b]{2}{*}{ Uraian } & \multirow[b]{2}{*}{ Pendapatan } & \multicolumn{2}{|c|}{ Biaya } & \multirow[b]{2}{*}{ Keuntungar } \\
\hline & & Input tradable & $\begin{array}{c}\text { Input Non Tradable } \\
\text { (Faktor domestik) }\end{array}$ & \\
\hline Privat & A & $\mathrm{B}$ & C & D \\
\hline Sosial & $E$ & $\mathrm{~F}$ & G & $\mathrm{H}$ \\
\hline Efek Divergensi & I & J & K & $\mathrm{L}$ \\
\hline
\end{tabular}

Sumber: Pearson, dkk (2005)

Keterangan: $\mathrm{A}=$ Pendapatan Privat, $\mathrm{B}=$ Biaya privat untuk input tradable, $\mathrm{C}=$ Biaya privat untuk input non tradable, $\mathrm{D}=$ Keuntungan Privat, $\mathrm{E}=$ Pendapatan sosial, $\mathrm{F}=$ Biaya sosial untuk input tradable, $\mathrm{G}=$ Biaya sosial untuk input non tradable (faktor domestik), $\mathrm{H}=$ Keuntungan sosial, $\mathrm{I}=$ Tingkat divergensi revenue, J- Tingkat divergensi biaya input tradable, $\mathrm{K}=$ Tingkat divergensi biaya input non tradable (faktor domestik), L= Dampak total dari seluruh divergensi.

1. Keunggulan Komparatif dihitung dengan menggunakan Domestic Resource Cost Ratio $(D R C R)=\frac{G}{(E-F)}$. Sedangkan keunggulan kompetitif dihitung dengan menggunakan Private Cost Ratio $(P C R)=\frac{C}{(A-B)}$. Keunggulan komparatif dan Kompetitif diperoleh apabila nilai nilai keduanya kurang dari satu (DRCR<1).

2. Dampak kebijakan pemerintah terhadap output dapat diketahui dari besar proteksi pemerintah terhadap harga output tersebut. Kebijakan yang bersifat protektif apabila mendapatkan nilai lebih dari satu. Rumus yang digunakan adalah Nominal Protection Coefficient on Output $(\mathrm{NPCO})=\frac{A}{E}$, demikian juga dampak kebijakan pemerintah terhadap Input tradable dapat diketahui dari besar proteksi pemerintah terhadap harga input tradable tersebut. Kebijakan yang bersifat protektif apabila mendapatkan nilai kurang dari satu. Rumus yang digunakan adalah Nominal Protection Coefficient on Input $(\mathrm{NPCI})=\frac{B}{F}$. Sedangkan Intervensi pemerintah terhadap input domestik (Faktor Transfer) dilakukan pemerintah dengan cara pemberian subsidi positif pada input domestik tersebut sehingga nilainya akan lebih besar dari satu. Rumus yang digunakan adalah $\mathrm{C} / \mathrm{G}$.

Dampak kebijakan pemerintah terhadap Input dan Output secara simultan dapat diketahui dengan semakin tingginya nilai proteksi pemerintah terhadap komoditi tersebut yang dihutung dengan menggunakan rumus Effective Protection Coefficient $(E P C)=\frac{(A-B)}{(E-F)}$.

Adanya subsidi pada sistem usahatani jagung secara keseluruhan juga merupakan faktor pendukung dari dampak kebijakan pemerintah terhadap usahatani tersebut secara simultan sehingga nilainya akan lebih besar dari satu. Rumus yang digunakan adalah Koefisien Keuntungan $(\mathrm{PC})=\frac{D}{H}$. Selain itu untuk melihat kebijakan pemerintah yang berlaku menyebabkan petani jagung mengeluarkan biaya produksi lebih kecil dari opportunity cost jika Rasio subsidi pada produsen (SRP) lebih besar dari satu. Rumus yang digunakan adalah $\mathrm{SRP}=\frac{L}{E}$. 


\section{HASIL DAN PEMBAHASAN}

Setelah menentukan harga privat dan sosial dari setiap variabel input dan output, kemudian dihitung menggunakan policy analysis matrik (PAM) agar dapat menentukan keunggulan komparatif dan kompetitif usahatani jagung di Kabupaten Bengkayang beserta kebijakan pemerintah yang berlaku pada usahatani tersebut.

1. Keunggulan Komparatif dan Keunggulan Kompetitif

Nilai DRCR usahatani jagung dari hasil penelitian adalah sebesar 0.59 atau DRCR < 1. Nilai DRCR ini menunjukkan bahwa usahatani jagung di Kabupaten Bengkayang memiliki keunggulan komparatif dan mampu memanfaatkan sumberdaya domestik yang ada untuk menggantikan jagung impor guna memenuhi kebutuhan lokal. Nilai tersebut juga dapat diartikan bahwa untuk memproduksi jagung di Kabupaten Bengkayang sebagai suplay jagung kalimantan barat hanya membutuhkan biaya sumberdaya domestik sebesar 59 persen terhadap biaya impor yang akan dibutuhkan. Dengan kata lain, setiap Rp 1; yang dibutuhkan untuk mengimpor produk tersebut, hanya membutuhkan biaya domestik sebesar Rp 0,59.

Nilai PCR usahatani jagung juga menunjukkan bahwa usahatani jagung di Kabupaten Bengkayang memiliki keunggulan kompetitif karena nilai PCR yang didapat sebesar 0,81 atau $\mathrm{PCR}<1$. Dengan kata lain, untuk meningkatkan nilai tambah output sebesar Rp 1; pada harga privat maka usahatani jagung di Kabupaten Bengkayang hanya memerlukan tambahan biaya non tradable sebesar Rp 0,81 atau kurang dari satu satuan. Dengan nilai PCR sebesar 0,81 maka usahatani jagung memiliki kemampuan terbatas dalam membiayai input non tradablelnya atau dengan kata lain tidak tertutupnya biaya produksi jika harga output pada tingkat harga privat semakin menurun. Nilai PCR yang mendekati nilai satu sangat rentan terhadap perubahan eksternal yang akan terjadi (Saptana 2005). Sehingga dikatakan mempunyai kemampuan yang sangat terbatas untuk membiayai faktor nontradablenya. Hal ini disebabkan karena tidak adanya kebijakan pemerintah terhadap harga output jagung sehingga sangat rentan terjadinya kegagalan pasar (monopsoni).

Hasil penelitian BPTP Kalimantan Barat (2006) Permasalahan agribisnis jagung di Kabupaten Bengkayang diantaranya adalah harga jual jagung yang relatif rendah. Benny (2001) dalam penelitiannya mengungkapkan bahwa Rendahnya harga jagung di tingkat petani masih dirasakan sebagai issu permasalahan yang perlu diatasi. Untuk itu perlu terus dijalin suatu kemitraan antara petani produsen dengan industri pangan atau pakan. Upaya meningkatkan efisiensi produksi, maka areal pengembangan jagung perlu dikaitkan dengan sistem pemasaran hasil yang efisien.

Kurangnya proteksi pemerintah terhadap hasil jagung petani, semakin memperparah kondisi usahatani jagung di Kabupaten Bengkayang khususnya dan Kalimantan Barat pada umumnya. Akibat yang sangat jelas terlihat pada produksi jagung Bengkayang yang tidak bisa memenuhi ketentuan kuantitas stok dan kontuinitasnya, dimana para buyers yang dalam hal ini perusahaan Pakan Ternak Singkawang menargetkan pembelian hingga 250.000 ton pada tahun 2012, namun belum mampu dipenuhi sehingga jagung produksi lokal tidak diminati buyers, hal ini jelas sangat mempengaruhi pada tingkat daya saing komoditi jagung Kalimantan Barat (Dinas Pertanian Tanaman Pangan dan Hortikultura, 2013). 
Khadijah (2002) dalam Zulkifli Mantau (2009) mengemukakan bahwa produk pertanian Indonesia masih kalah bersaing dari kuantitas maupun harga dibanding dengan negara lain. Di negara-negara barat sistem pertanian sudah sangat efisien dengan produktivitas yang tinggi sehingga mampu menjual dengan harga murah. Sedangkan Indonesia produktivitasnya masih rendah.

Penelitian Khadijah (2002) dalam Zulkifli Mantau (2009) tersebut ternyata relevan dengan kenyataan di Kabupaten Bengkayang. Berdasarkan temuan di lapangan menunjukkan bahwa harga produksi jagung pipil kering yang berlaku di lokasi penelitian dihargai lebih rendah dibandingkan dengan harga jagung impor. Alasan buyers membeli jagung Bengkayang dengan harga rendah bukan karena kualitas yang tidak memenuhi syarat, akan tetapi kuantitas yang diharapkan selalu tersedia untuk mencukupi kebutuhan bahan baku perusahaan dalam membuat pakan ternak.

Sehubungan dengan hal tersebut, berdasarkan hasil perhitungan Nominal Protection Coefficient on Output (NPCO) diperoleh hasil sebesar 0,79 yang menunjukkan bahwa petani sebagai produsen menerima harga output aktual lebih rendah dari harga CIF jagung impor yang pada tahun 2014 berada pada harga $\mathrm{Rp}$ 3.900 per $\mathrm{kg}$. Hal ini sesuai dengan data hasil wawancara di lapangan yang menunjukkan bahwa harga jual produk jagung petani di lokasi penelitian pada tahun 2014 hanya rata-rata Rp. 3.098,53 per kg atau berada pada kisaran Rp. 3.100. Sehingga disarankan agar pemerintah dapat memberikan kebijakan proteksi pada harga output dengan mensubsidi harga output domestik sehingga mendongkrak naiknya harga output domestik dibanding harga efisiensinya (harga dunia).

2. Analisis Dampak Kebijakan Pemerintah

Dampak kebijakan pemerintah terhadap harga output yang diukur dengan menggunakan Nominal Protection Coefficient on Output (NPCO) menghasilkan nilai sebesar 0,79 atau kurang dari satu $(\mathrm{NPCO}<1)$, keadaan ini menunjukkan bahwa kebijakan daerah mengenai usahatani jagung bersifat disinsentif terhadap output. Artinya tidak ada bantuan ataupun intervensi pemerintah baik melalui subsidi harga pembelian maupun proteksi atau pengendalian harga beli aktual, terhadap hasil jagung petani tersebut.

Kenyataan di lapangan menunjukkan bahwa adanya ketergantungan para petani pada pedagang pengumpul desa atau dengan kata lain para pedagang pengumpul di masing-masing desa penelitian menjadi satu-satunya pembeli hasil panen dan tempat bergantung petani untuk aspek pengadaan sarana input produksi. Sehingga para pedagang pengumpul tersebut memiliki kekuatan dalam mengendalikan harga input dan output. Keadaan ini menyebabkan tingkat permainan harga relatif tinggi, sebab para pedagang pengumpul mampu mempermainkan harga sementara masing-masing petani tidak punya pilihan lain karena terdesak kebutuhan dan belum adanya acuan harga yang baku dari pemerintah terhadap pembelian hasil jagung mereka. Rantai tataniaga produksi jagung sampai ke konsumen akhir akan menentukan harga aktual jagung. Ratarata harga jagung pipil kering di tingkat petani sebesar Rp3,098.53 per $\mathrm{kg}$ sedangkan harga di tingkat konsumen akhir sebesar Rp 3.700; per kg. Terdapat selisih harga yang besar yaitu Rp 601,47 per kg diantara kedua harga tersebut.

Oleh karena itu sangat perlu bagi pemerintah daerah merumuskan kebijakan yang lebih operasional sehingga dapat mengangkat kembali tingkat daya saing 
jagung di Kabupaten Bengkayang. Faroby dan Arif (2008) mengungkapkan bahwa komponen harga merupakan komponen yang paling sensitif terhadap keuntungan pengusahaan komoditi jagung. Menurut Ikin (1999), perbaikan mekanisme pasar jagung harus lebih kondusif, termasuk didalamnya kelembagaan, sarana dan prasarana pasar input/output, sampai ke perbaikan system pasca panen. Sebab tanpa ada upaya dan terobosan baru kearah itu, hampir mustahil swasembada dan daya saing jagung dalam Kalimantan Barat dapat tecapai lebih baik.

Dampak kebijakan pemerintah terhadap harga input yang diukur dengan menggunakan Nominal Protection Coefficient on Input (NPCI) menghasilkan nilai sebesar 0,71 atau lebih kecil dari satu $(\mathrm{NPCI}<1)$. Keadaan ini menunjukkan bahwa pemerintah memproteksi harga input tradable terutama pada pupuk bersubsidi di pasar domestik di bawah harga efisiennya. Dapat dikatakan juga bahwa total biaya input yang bisa dihemat sebesar 71 persen dari biaya yang seharusnya dikeluarkan petani jagung untuk memproduksi usahatani jagungnya jika subsidi dari pemerintah ditiadakan.

Kebijakan subsidi dari pemerintah dapat memberikan manfaat besar bagi petani jagung apabila pendistribusiannya sudah sesuai dengan ketentuan yang telah ditetapkan oleh pemerintah. Syafa'at dkk. (2007) dalam kajiannya mengemukakan bahwa terdapat kekuatan dan kelemahan subsidi pupuk langsung ke produsen pupuk ataupun ke petani yaitu: Pengelolaan subsidi relatif mudah, tidak diperlukan identifikasi petani penerima subsidi sehingga pengecer resmi dapat menjual pupuk bersubsidi kepada siapa saja baik petani yang berhak maupun bukan. Pupuk bersubsidi justru dijual ke PPD karena terdapat kebebasan distributor tingkat kecamatan untuk menjual pupuk bersubsidi kepada siapapun sehingga harga pupuk di tingkat petani kecil ditentukan oleh PPD. Efektivitas dalam meningkatkan daya beli petani untuk membeli pupuk relatif tinggi. Hal ini berlaku dengan syarat apabila efektivitas harga eceran tertinggi (HET) terjamin.

Kondisi di lapangan menunjukkan bahwa rata-rata harga aktual pupuk bersubsudi yaitu urea sebesar Rp 2.333,91 dan phonska Rp 3.015,49. Padahal kedua pupuk ini memiliki Harga Eceran Tertinggi (HET) yang diatur oleh pemerintah dalam Peraturan Menteri Pertanian Republik Indonesia Nomor 122/Permentan/ SR.130/11/2013 yang masing-masing sebesar Rp. 1.800; per kg untuk harga urea dan Rp 2.300; per kg untuk pupuk ponska. Fenomena tersebut jelas memperlihatkan belum operasionalnya kebijakan mengawasan subsidi pupuk yang diterapkan pemerintah selama ini. Oleh karena itu perlu adanya alternatif kebijakan untuk mengatasi hal tersebut.

Darwis dan Nurmanaf (2004) dalam kajiannya mengemukakan bahwa beberapa kebijakan strategis yang perlu dipertimbangkan pemerintah menyangkut masalah pupuk di tingkat usahatani, yaitu: (1) rasionalisasi penggunaan pupuk di petani, (2) rekomendasi pupuk berdasarkan atas analisis tanah spesifik lokasi, (3) peningkatan efektivitas penggunaan pupuk anorganik yang dikomplemen dengan pemanfaatan pupuk organik, (4) perbaikan pelaksanaan standarisasi dan sertifikasi pupuk, dan (5) pelaksanaan kebijakan ekspor dan impor pupuk yang kondusif bagi kontinuitas dan harga pupuk di tingkat petani.

Selain input yang diperdagangkan, petani jagung juga menggunakan input domestik (lahan, tenaga kerja, bibit jagung lokal dan pupuk kandang) yang tidak diperdagangkan di pasaran dunia. Besaran yang menunjukkan perbedaan antara 
harga sosial dan harga sesungguhnya yang diterima produsen untuk pembayaran faktor produksi yang tidak diperdagangkan disebut transfer faktor (TF). Nilai transfer faktor pada komoditas jagung di Kabupaten Bengkayang sebesar 1,10 atau bernilai lebih besar dari satu $(\mathrm{TF}>1)$ yang artinya bahwa biaya usahatani untuk barang-barang domestik yang tidak diperdagangkan dibayar lebih tinggi dibandingkan dengan harga sesungguhnya jika terjadi persaingan sempurna. Dengan kata lain terdapat kebijakan pemerintah yang melindungi produsen input domestik.

Apabila dilihat dari dampak kebijakan pemerintah terhadap Input dan Output secara simultan terhadap usahatani jagung Kabupaten Bengkayang yang dihutung dengan menggunakan rumus Effective Protection Coefficient (EPC) menghasilkan nilai sebesar 0,81 atau lebih kecil dari satu (EPC $<1)$. Nilai EPC lebih kecil dari satu mengandung arti bahwa secara simultan tidak terdapat kebijakan pemerintah terhadap harga output maupun input yang melindungi produsen jagung di Kabupaten Bengkayang. Kenyataan di lokasi penelitian, kebijakan subsidi input usahatani jagung sudah menunjukkan keberpihakan pemerintah terhadap petani, namun subsidi pada harga input tersebut tidak cukup menguntungkan bagi pengembangan dan peningkatan produksi pada pengusahaan komoditas jagung di Kabupaten Bengkayang hal ini disebabkan karena tidak adanya kebijakan harga yang ditetapkan oleh pemerintah terhadap harga output. Suprapto (2006) dalam hasil penelitiannya mengemukakan bahwa komoditas jagung yang digunakan untuk orientasi subtitusi impor dan perdagangan antar daerah tidak memperoleh proteksi pada harga outputnya, namun hanya memperoleh subsidi pada input usahataninya. Sehingga sangat relevan jika dihubungkan dengan hasil penelitian ini, kebijakan yang diberikan oleh pemerintah hanya sebatas proteksi input tanpa ada kebijakan proteksi pada harga output.

Produksi jagung di Kabupaten Bengkayang akan cendrung menurun jika tidak diimbangi dengan kebijakan pemerintah yang berpihak kepada petani terutama pada penetapan harga output. Hal ini berarti komoditas jagung di Kabupaten Bengkayang memerlukan proteksi dari pemerintah, sehingga produsen tetap mau berproduksi (surplus produsen meningkat). Sebaliknya apabila tidak ada rangsangan yang diterima oleh petani, tidak menutup kemungkinan petani akan beralih menanam komoditas lainnya. Keadaan ini didukung oleh Nilai Coeffisien profitability (PC). Hasil perhitungan PC mendapatkan hasil sebesar 0,39 atau lebih kecil dari satu $(\mathrm{PC}<1)$ yang berarti bahwa keuntungan yang diterima produsen yang mengusahakan komoditas jagung lebih kecil jika dibandingkan dengan keuntungan bersih sosialnya. Sejalan dengan hal tersebut, Rasio Subsidi Produsen (SRP) pada komoditas jagung di Kabupaten Bengkayang juga bernilai kurang dari satu atau sebesar -0,20. Artinya dengan adanya kebijakan pemerintah saat ini, produsen atau petani yang mengusahakan komoditas jagung membayar biaya produksi dengan nilai lebih tinggi dari biaya imbalan berproduksinya (opportunity cost) atau dengan kata lain, subsidi pada harga input yang diberikan oleh pemerintah saat ini tidak cukup menguntungkan bagi pengembangan dan peningkatan produksi pada pengusahaan komoditas jagung di Kabupaten Bengkayang. 


\section{KESIMPULAN DAN SARAN}

Berdasarkan tujuan serta hasil dan pembahasan dalam penelitian ini, dapat disimpulkan beberapa hal, yaitu:

1. Secara umum usahatani jagung di Kabupaten Bengkayang memiliki keunggulan komparatif dan kompetitif. Penerapan sistem kontrol yang ketat dan evaluasi secara berkala dari pihak pemerintah terhadap kebijakan yang telah diterapkan sangat berpengaruh pada peningkatan keunggulan kompetitif di tingkat masyarakat petani jagung yang akan berdampak pada pengembangan produktifitas jagung ke depan. Perlu adanya penelitian lanjutan mengenai keunggulan komparatif dan kompetitif ini terutama pada Kabupaten/Kota yang juga merupakan wilayah pengembangan jagung di Kalimantan Barat seperti Kota Singkawang, Kabupaten Kubu Raya dan Kabupaten Mempawah. Sehingga dapat diperoleh suatu basis data mengenai posisi keunggulan komparatif dan kompetitif komoditas jagung di Kalimantan Barat.

2. Kebijakan pemerintah untuk input usahatani jagung sudah menunjukkan keberpihakan terhadap petani, namun subsidi pada harga input tersebut tidak cukup menguntungkan bagi pengembangan dan peningkatan produksi pada pengusahaan komoditas jagung di Kabupaten Bengkayang jika tidak diikuti dengan kebijakan harga output misalnya dengan menerapkan harga pembelian daerah. Hal ini sebagai upaya untuk mengontrol pasar agar harga ditingkat petani tidak dipermainkan oleh para pedagang pengumpul.

\section{DAFTAR PUSTAKA}

Balai Pengkajian Teknologi Pertanian Kalimantan Barat, 2001. Teknologi Budidaya Padi Tanam Benih Langsung (Tabela) Di Lahan Sawah Pasang Surut. Pusat Penelitian Pengembangan Sosial Ekonomi Pertanian. Departemen Pertanian.

Bank Indonesia, 2014. Laporan Tinjauan Kebijakan Moneter (Ekonomi, Moneter dan Perbankan) April 2014. Bank Indonesia. Jakarta.

Darwis, V. dan A.R. Nurmanaf. 2004. Kebijakan Distribusi, Tingkat Harga dan Penggunaan Pupuk di Tingkat Petani. Jurnal Forum Penelitian Agro Ekonomi, 22 (1) : 63 - 73.

Dinas Pertanian Tanaman Pangan dan Hortikultura Propinsi Kalimantan Barat Tahun 2012. Program Peningkatan Produksi Jagung di Kalimantan Barat Dalam Menuju Swasembada Pangan 2013. Pontianak.

Falatehan, A.F dan A. Wibowo. 2008. Analisis Keunggulan Komparatif dan Kompetitif Pengusahaan Komoditi Jagung di Kabupaten Grobongan. Jurnal Agribisnis dan Ekonomi Pertanian. Volume 2. No 1 - Juni 2008. Departemen Ekonomi Sumberdaya Lingkungan. Fakultas Ekonomi dan Manajemen IPB. Bogor. http://journal.ipb.ac.id/index.php/jurnal agribisnis/article/view/5988

Mantau, Z. 2009. Analisis Keunggulan Komparatif dan Kompetitif Usahatani Jagung dan Padi di Kabupaten Bolaang Mongondow Propinsi Sulawesi Utara. Tesis Magister Sains. Program Pascasarjana, Institut Pertanian Bogor, Bogor. 
Mantau, Z., Bahtiar dan Aryanto. 2005. Analisis dayasaing Usahatani Jagung di Kabupaten Bolaang Mongondow Propinsi Sulawesi Utara. Balai Pengkajian Teknologi Pertanian (BPTP) Sulawesi Utara

Pearson, S., C. Gotsch dan S. Bahri. 2005. Aplikasi Policy Analysis Matrix pada Pertanian Indonesia. Terjemahan.Yayasan Obor Indonesia, Jakarta.

Rachman, B. 2001. Dinamika Harga dan Perdagangan Komoditas Jagung. Pusat Penelitian Sosial Ekonomi Pertanian. Bogor. ojs.unud.ac.id/index.php/soca/article/download/4019/ 3008

Saptana. 2010. Keunggulan Komparatif-Kompetitif dan Strategi Kemitraan. Pusat Penelitian dan Pengembangan Sosial Ekonomi Pertanian Badan Litbang Pertanian. Departemen Pertanian RI. Jurnal Sosial Ekonomi Pertanian dan Agribisnis (SOCA). Universitas Udayana. Bali_http://ojs.unud. ac.id/index.php/ soca/article/viewFile/4196/3181

Suprapto, 2006. Keunggulan Komparatif dan Dampak Kebijakan Produksi Jagung di Propinsi Jawa Timur. Buletin Penelitian Puslit Universitas Mercubuana, (10) : 89-106.

Syafa'at, N., A. Purwoto, K.M. Noekman, I.S. Anugerah, E. Suryani, Y. Marisa, A. Askin dan M. Suryadi. 2007. Kaji Ulang Sistem Subsidi dan Distribusi Pupuk. Makalah Seminar Hasil Penelitian. Pusat Penelitian Sosial Ekonomi dan Kebijakan Pertanian (PSE-KB), Bogor. www.pse.litbang. deptan.go.id 